Deus como "luz"

no Cristianismo e no Islã:

Literatura comparada e

teologia da Revelação

God as "light" in Christianity and Islam:

Comparative Literature and

Theology of Revelation
Texto enviado em

21.06.2018

e aprovado em

11.08.2019

V. 10 - N. $20-2020$

*Doutor em Teologia pela

Pontifícia Universidade

Gregoriana e Professor de Teologia no PPGT PUC PR. Contato: marcialscj@ gmail.com

\section{Marcial Maçaneiro*}

\section{RESUMO}

Este artigo examina os textos sacros em que Deus é nomeado Luz, no Cristianismo (Bíblia) e no Islã (Alcorão), como expressão literário-teológica do monoteísmo abraâmico. Do ponto de vista literário, parte-se do contexto de solarização das divindades médio-orientais e egípcias, com seus registros, para se abordar as páginas bíblicas e corânicas em que Deus recebe atributos de luminosidade, brilho e esplendor, como Luz. Essa literatura é analisada a partir do uso análogo ou metafórico da luz como qualidade divina, mediante abordagem comparada de textos bíblicos e corânicos. Dentre dezenas de citações, destacam-se textos sapienciais, proféticos, joaninos e paulinos, da Bíblia; bem como as Suras que se referem à luminosidade solar e divina, especialmente o Verso da Luz (Sura 24,35) que é um poema. Do ponto de vista teológico, explicitam-se as questões hermenêuticas dos referidos textos para a teologia da Revelação no Cristianismo e no Islã, indo-se da linguagem (o falar de Deus) à ontologia (o ser de Deus). Tal exame busca subsídio em comentadores dos textos sacros, especialmente aqueles que tratam do Nome divino da Luz, como o Pseudo-Dionísio e Schökel, Al-Gazali 
e Al-Razi, entre outros. À conclusão, nota-se a argumentação pendular entre afirmação e negação de Deus como luz nos dois Credos, por via mística (a Luz como acesso ao Deus abscôndito) ou por via dialética (a Luz como metáfora do Deus relevado).

Palavras-chave: Nomes de Deus. Luz. Revelação. Cristianismo. Islã.

\section{ABSTRACT:}

This paper examines the sacred texts in which God is named Light, in Christianity (Bible) and Islam (Quran), as literary-theological expression of Abrahamic monotheism. From the literary point of view, one starts from the context of solarization of the Middle Eastern and Egyptian deities, with their records, to approach the biblical and quranic pages in which God receives attributes of luminosity, brilliance and splendor, as Light. This literature is analyzed from the analogous or metaphorical use of light as divine quality, by comparative approach of biblical and quranic texts. Among dozens of quotations, we can highlight sapiential, prophetic, Johannine and Pauline texts of the Bible; as well as the Suras which refer to the solar and divine luminosity, especially the Verse of Light (Sura 24,35 ) - a beautiful poem. From a theological point of view, the hermeneutic questions of the texts for the theology of Revelation in Christianity and Islam are explained from language (the speaking about God) to ontology (the being of God). Such an examination seeks support in commentators of sacred texts, especially those dealing with the divine Name of Light, such as Pseudo-Dionysius and Schökel, Al-Gazali and Al-Razi, among others. In conclusion, one can note the pendular argument between affirmation and denial of God as light in the two Creeds, mystically (the Light as access to the hidden God) or dialectically (the Light as a metaphor of the revealed God).

Key-words: Names of God. Light. Revelation. Christianity. Islam.

\section{Introdução ce \\ eus é luz" proclamam a Bíblia e o Alcorão (1Jo 1,5; Sura 24,35), em páginas carregadas de valor literário e teoló- gico1. A experiência originária de viver sob o Sol, acom-}

1. Para as citações bíblicas usamos a Bíblia de Jerusalém (Paulus, 2002) e o Novo Testamento Grego (Sociedade Bíblica do Brasil, 2012). Para as citações corânicas usamos a tradução anotada de Peirone (Mondadori, 2003) em cotejo com a edição bilíngue anotada de Mandel (UTET, 2004). 
panhando seu curso celeste ao longo das estações, levou muitos povos a divinizar o altíssimo Astro. A esta divinização do Sol seguiu-se a solarização das divindades, especialmente no cenário médio-oriental e egípcio. Peças arqueológicas e literárias o demonstram, adentrando inclusive no terreno bíblico. A partir dos exílios, o Povo da Aliança rememorou o patriarca Abraão e releu sua História como revelação do Deus Único, Adonai (IHWH). Não só a Torah, mas a literatura sapiencial e profética da Bíblia afirma a Deus como Criador e Altíssimo, distinto de todas as criaturas, especialmente daquelas divinizadas como o Sol, a Lua e eventualmente o fogo. Esta distinção se consolida: marca profundamente o monoteísmo de herança abraâmica, alcança a literatura do Novo Testamento na pena de João e Paulo, problematiza a questão dos atributos de Deus e sua compreensão teológica. Na trilha de Abraão se põe, também, Muhammad e sua Récita, o Alcorão. Como ocorreu com a narrativa bíblica, também a Récita foi compilada e tornou-se Livro Santo. De novo, vem à cena os atributos de Deus, numa argumentação que vai da analogia à ontologia.

Os textos se fazem Revelação. A inteligência crente de cristãos e muçulmanos perscruta os Livros. Examina os termos. Elenca os atributos de Deus e sonda-Ihe os Nomes, numa elaborada hermenêutica. Os escritos se fazem teologia, sem abandonar sua beleza poética e seus jogos metafóricos: Deus continua brilhando como Luz, mais radiante que o Sol e mais cintilante que as estrelas que, aliás, Ele mesmo criou. Assim o dizem, como veremos, o Salmista e o apóstolo Paulo, Muhammad e as máximas da Suna, seguidos de seus comentadores, como o PseudoDionísio e mais tarde Tomás de Aquino, entre os cristãos; ou Al-Gazali e Al-Razi, entre os muçulmanos. Abrem-se vias de interpretação literário-teológica da Luz como Nome próprio de Deus, entre a negação (não é um Nome essencial, mas recurso de linguagem) e a afirmação (é atributo próprio, expressão da essência divina). Nas páginas que seguem percorremos essas vias, relendo a literatura bíblica e corânica e examinando seus intérpretes. Por fim, tecemos nossas observações sobre a 
Luz como Nome divino, a partir das Escrituras e seus comentadores, na tensão entre dialética e mística.

\section{Analogia da luz aplicada à Divindade}

A luz e, mais precisamente, a luz solar, tem sido associada à divindade desde os primórdios da religião, especialmente no cenário mediterrâneo e médio-oriental. Na antiga Mesopotâmia, em 2600 a.C. aproximadamente, ideogramas semelhantes a um asterisco [ * ] representavam o Céu como morada do divino: "toda divindade era imaginada como um ser celeste; eis por que deuses irradiavam uma luz muito forte" (ELIADE, 2010, p. 67). Na evolução linguística da região, o termo acádico Shamash torna-se o nome próprio do deus Sol, sobrevivendo até hoje no hebraico shemesh e no árabe shams - termos que nomeiam o astro rei. Da antiga religião indo-europeia ao culto dos mesopotâmicos, a luz solar é identificada como "o deus manifesto por excelência" e "fonte de sacralidade" (ELIADE, 2010, p. 95 e 103), marcando fortemente a percepção e a linguagem religiosa do Oriente Médio - berço do Judaísmo, Cristianismo e Islã. Daí o uso da luz, do Sol e da aurora como símbolos ou metáforas da divindade, com seus atributos de luminosidade, energia e poder criador. Outro registro nos vem da Índia. A partir de 1700 a.C. o Rig Veda usa o termo hindo-europeu dyaus para designar "o céu diurno em que brilha o sol resplandecente" (BOYER, 1995, p. 57). Do termo dyaus derivaram o grego Zeus e o latino Deus, com Júpiter e Zeus na posição mais alta, representados como senhores do céu, do raio e do trovão (cf. BOYER, 1995, p. 66).

Contemplando o Sol, as religiões estabelecem a distinção da claridade, da ordem, do calor e da vida em face da treva, do caos, do frio e da morte, com suas dualidades e contrapontos (cf. BOYER, 1995, p. 66). A abóbada celeste, presidida pelo Sol, é vista como "tenda" que cobre a Terra (SI 104,2 e Is 40,22) e "pergaminho" que se desenrola sobre nossos olhos de leitores do mundo (Sura 39,5). De noite, a Lua reflete 
os raios do cálido astro; na aurora, o Sol esparge sua luz que cobre de dourado a terra, como o próprio termo sugere: aurora vem do latim aurea hora, a hora dourada das matinas, quando judeus, cristãos e muçulmanos elevam a Deus os primeiros louvores.

Um dos desenvolvimentos mais eloquentes dessa "solarização" do culto divino, como diz Eliade (2010, p. 107), deu-se no Egito. Primeiramente, com a adoração de Amon-Rá, o deus Sol cujo centro de culto era Tebas. Amon-Rá se destacava no panteão dos deuses egípcios, como energia criadora que, no poente, enfrenta as trevas para derrotar Apófis, o Caos devorador do mundo, para depois ressurgir glorioso no alvorecer do dia. Uma segunda expressão da solarização da divindade deu-se durante o reinado do faraó Akhenaton, de 1351 a 1334 a.C. aproximadamente. Antes chamado Amen-Hotep, o faraó muda seu nome para Akhen-Aton, literalmente Servo de Aton - o deus Sol radiante, sem pares nem oponentes - e realiza uma reforma radical no culto egípcio: decreta a abolição do culto a Amon-Rá e de todo o panteão tradicional, para entronizar Aton, simbolizado pelo disco áureo e pelos raios, proclamado a "única divindade suprema" e "fonte universal da vida" (ELIADE, 2010, p. 110-111). Um magnífico hino a Aton, escrito nas paredes do túmulo egípcio de Api, assim proclama:

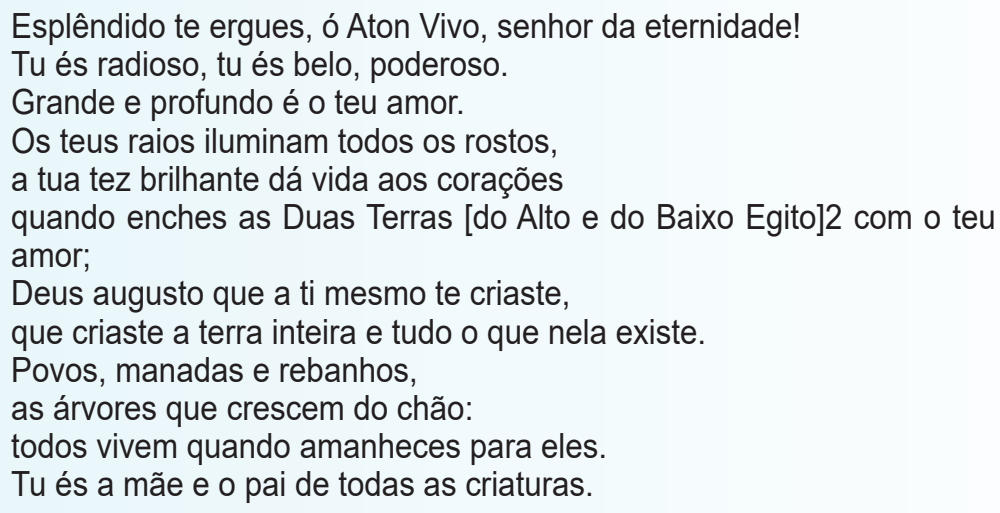

2. Conforme lemos nas versões paralelas inscritas no túmulo egípcio de Ai (cf. CARREIRA, Paulo. Textos da religião de Aton. In: Revista Lusófona de Ciência das Religiões. Lisboa, ano III, 2004, n. 5-6, p. 252). 
Os olhos delas voltam-se para ti, quando ascendes no firmamento, quando os teus raios iluminam toda a terra; os corações abrem-se num clamor à tua vista quando te levantas como o seu Senhor.

(Pequeno Hino a Aton, estrofe 1: CARREIRA, 2004, p. 256-257)

Outro exemplo nos vem do Zoroastrismo, que vê o Sol como metáfora da divindade, sem, contudo, concebê-lo como deus. Zoroastro, que teria vivido entre 628 e 551 a.C. segundo Eliade (2010, p. 290), expressa uma concepção monoteísta do divino, por ele denominado Ahura Mazda, literalmente "Senhor Sábio" (DUCHESNE-GUILLEMIN, 1984, p. 1275). Seus atributos de luz, sabedoria e poder criador se transparecem no Sol, mas sem confusão entre esta estrela e Ahura Mazda, divindade suprema, benéfica e criadora. De fato, Zoroastro não propõe a adoração do Sol, mas sim a reverência ao fogo flamejante, aceso em piras no interior dos templos, como sinal da presença potente e luminosa de Ahura Mazda.

Deste modo, a luz em geral e, particularmente, a luz do Sol tem-se estabelecido como símbolo e metáfora dos deuses: sua perenidade nos Céus e sua potência sobre a Terra ao longo das estações é vista como hierofania, sugerindo muitas analogias entre as qualidades solares e os atributos divinos. Exemplos semelhantes multiplicam-se na História religiosa dos povos, avolumando-se em muitas páginas se quiséssemos traçar aqui uma sinopse.

\section{Deus-Luz nas religiões abraâmicas}

Dando um passo em nosso estudo, perguntamo-nos: em que medida as tradições judaico-cristã e islâmica acolhem esta solarização da divindade? Como dá-se a continuidade ou descontinuidade dessas religiões a respeito dos cultos milenares referidos à luz diurna? - Nossa resposta parte de uma primeira observação: as tradições judaico-cristã e islâmica mantêm o simbolismo da luz e do Sol para referir-se ao Deus Único; porém o fazem mais como analogia e menos como ontologia do 
Deus que professam. Com efeito, a literatura bíblica e corânica aplicam a Deus algumas qualidades solares e luminosas como termos de comparação que enaltecem o Criador, enquanto preservam a exclusividade do Ser divino, jamais equiparado a qualquer astro ou potência natural. O salmista proclama: "O céu celebra a tua maravilha, ó Senhor [IHWH]: quem sobre as nuvens é como o Senhor [IHWH]? Pois teu é o céu; e a terra te pertence!" (SI 89,6-7.12); e Muhammad, no Alcorão, instrui: "Foi Allah quem erigiu os céus sem colunas aparentes; logo assumiu o Trono e submeteu o Sol e a Luz à sua vontade; cada qual prosseguirá o seu curso, até um término prefixado" (Sura 13,2, com paralelo na Sura 35,13 ).

Nesse caso, tanto a Bíblia como o Alcorão zelam pelo culto exclusivo do Deus Criador, adorado como O Único (ehad em hebraico; ahad em árabe). Nessa literatura, a afirmação de soberania do Único Deus sobre os astros e as potências celestes estabelece uma distinção com os cultos de adoração do Sol e da Lua, e corrige a superstição corrente entre muitas tribos semitas - de que os eclipses e a passagem de cometas seriam ocasião "de bom ou mau agouro" por determinação das divindades urânicas (NOJA, 2009, p. 177 e 182). Essa negação das divindades celestes em benefício do culto do Deus de Abraão opera um filtro hermenêutico nas narrativas judaico-cristãs e muçulmanas, aprimorado no longo processo de explicitação das experiências originárias e redação das respectivas Escrituras, ou seja, a Bíblia e o Alcorão.

Um exemplo particular deste processo hermenêutico encontra-se nos primeiros versos do Salmo 104. O exame crítico, segundo Schökel e Carniti (1998, p. 1281) "mostra que é cananéia a pátria mental e espiritual desse salmo, e que o Egito assimila a influência cananéia”, como vemos no Hino a Aton citado antes. Este Salmo toma as qualidades do Sol - cultuado como deidade entre mesopotâmicos e egípcios - e as atribui a Adonai (IHWH), enaltecido como Deus "soberano" que "apresenta-se com vestes régias e construiu para Si um palácio nas alturas" (SCHÖKEL, 2002, p. 1336): 
Bendize a Adonai [IHWH], ó minha alma!

Adonai [IHWH], Deus meu, como és grande:

vestido de esplendor e majestade,

envolto em luz como num manto,

estendendo os céus como tenda,

construindo sobre as águas [celestiais] as tuas altas moradas;

tomando a nuvens como tua carruagem,

caminhando sobre as asas do vento;

fazendo dos ventos teus mensageiros,

e das chamas de fogo, teus ministros! (SI 104,1-4)

A literatura profética também traz exemplos significativos, como Isaías: "Não terás mais o sol como luz do dia, nem o clarão da lua te iluminará, porque Adonai [IHWH] será tua luz para sempre, e teu Deus será teu esplendor. Teu sol não voltará a pôr-se, e tua lua não minguará, porque Adonai [IHWH] ter servirá de luz eterna" (Is 60,19-20). E Lucas evoca o Messias como o Astro luminoso que visita a humanidade: "Graças ao misericordioso coração de nossos Deus, pelo qual nos visita o Astro [anatolè] das alturas, para iluminar os que jazem nas travas e na sombra da morte, para guiar nossos passos no caminho da paz" (Lc 1,78-79). Em João, o próprio Messias declara-se luz: "Eu sou a luz do mundo [phos tou kosmou]: quem me segue não andará nas trevas, mas terá a luz da vida [phos tes zoès]" (Jo 8,12). Referida a Deus e a seu Verbo, a luz (phos) é um motivo teológico que João reitera em seu Evangelho nos capítulos 1,1-14; 3,19-21 e 12,34-36, com coroamento na Primeira Carta, ao afirmar: "Deus é luz e nele não há treva alguma" (1Jo 1,5). Voltando ao Prólogo, João nomeia a Jesus "luz do mundo" e "luz da vida", apresentando-o como o Logos pré-existente, participante da luz divina desde toda a eternidade, em quem a divindade se irradia (cf. Jo 1,9). "De fato - como diz Dodd (1977, p. 277) - a afirmação de ser a luz não poderia ser confirmada por nenhuma outra coisa, senão pelo brilhar da luz. É o conteúdo de todo o evangelho, que a obra de Cristo a si própria se comprova; suas obras são luminosas". Em seu conjunto, essas passagens evangélicas atestam a fé messiânica do Novo Testamento, atribuindo ao Cristo-Verbo o fulgor que no Primeiro Testamento pertencia à glória de Adonai (kavod IHWH). A respeito, compare-se a teofania 
do Sinai (Êx 3,1-15) com a revelação do Nome de Deus, e a teofania do Tabor (Mt 17,1-8) com a transfiguração radiante de Jesus.

O Islã, por sua vez, tem desenvolvimentos semelhantes sobre a luz divina - salvo a atribuição da mesma a Jesus, considerado Palavra (kalima) e Profeta (nabi), mas nunca divinizado (cf. Suras 5,72; 19,35). O atributo da luz compete a Allah e à Sua revelação (cf. Sura 24,35), corroborando a noção abraâmica de divindade: "Ele é Allah [Deus], o Único. Allah! O Absoluto! Jamais gerou, nem foi gerado! E ninguém é comparável a Ele" (Sura 112, em paralelo com Dt 6,4). Aliás, como explica Scattolin (2003, p. 13) o nome Allah é uma "contração do artigo singular al com o apelativo IL"- variação fonética de EL, o Deus semita - resultando "em al-Ilah (o-Deus), ou simplesmente Allah". Donde o reconhecimento de Muhammad para com judeus e cristãos: "Nosso Deus e vosso Deus são Um" (Sura 29,46).

Zeloso em preservar a unidade divina (tawhid), o Alcorão proclama Allah como Ser auto-subsistente de quem depende toda a ordem cósmica e natural: "Foi Ele quem originou o Sol esplendente e a Lua que reflete [clara luz]; e determinou as estações do ano, para que calculeis o número dos anos no curso dos tempos" (Sura 10,5). Em tom contundente, o mesmo Livro diz: "Entre os Seus sinais estão a noite e o dia, o sol e a lua. Não vos prostreis ante o sol nem ante a lua, mas prostrai-vos ante Allah, que os criou, se realmente é a Ele que quereis adorar" (Sura 41,37). Também as estrelas são luminares criados por Deus "para que vos orienteis na escuridão, seja na terra [ao caminhar], seja no mar [ao navegar]" (Sura 6,97). Do fenômeno físico do Sol e sua luz diurna deriva, por similitude, o sentido moral de treva e luz: "Aqueles que tomam nossos sinais [revelados] por mentira, são como surdos e mudos, mergulhados nas trevas" (Sura 6,39 com paralelo parcial na Sura 2,17). Em suma, para o Islã, o Criador está próximo a todos os seres, mas deles Se distingue substancialmente: Ele é sua fonte ou causa incriada; todos os demais seres estão "ontologicamente ligados e existencialmente dependentes de Deus" (IQBAL, 2009, p. 194). Deste modo, a literatura bíblica 
e corânica concordam em afirmar os atributos do Deus Único (eterno, auto-subsistente e Criador), essencialmente distintos dos atributos do Sol, da Lua e outros fenômenos astronômicos (criaturas temporais e não-subsistentes por si mesmas).

\section{A Luz como nome de Deus}

Nas narrativas bíblicas e corânicas o recurso à luz tem uma função literária e teológica. Quando usada ao modo de metáfora, a luz visível do Sol, de natureza criada e qualidades físicas, é tomada para adjetivar como luz ou luminoso o Deus Invisível, de natureza incriada e qualidades metafísicas: "O Senhor [IHWH] é Deus; Ele é a nossa luz" (SI 118,27); "Seu brilho é como a luz" (Hab 3,4). Quando usada como símbolo, a luz desempenha papel de representação ou título de Deus, seja para significar seu mistério, seja sua Revelação: "Adonai [IHWH] faça resplandecer o seu rosto sobre ti e te seja benigno" (Nm 6,25); "[Deus] habita em luz inacessível, que nenhum homem viu, nem pode ver" (1Tm $6,16)$; "De Allah vos chegou uma Luz" (Sura 5,15 ) ou "Allah conduz à Sua luz [à sua revelação] a quem Ihe apraz" (Sura 24,35 final).

Um aspecto interessante, para cristãos e muçulmanos, é que o pensamento por analogia encontra legitimidade na argumentação dos respectivos Livros sagrados. A Bíblia refere-se ao Deus da Aliança como Pastor (cf. Ez 34; SI 23) e Esposo (cf. Jr 2 - 3,1; Os 2,16-22), aplicando a Deus uma comparação de termos duplos: A está para $\mathrm{B}$, como $\mathrm{C}$ está para D; ou seja, o pastor está para o rebanho, como Deus está para o seu Povo; ou o esposo está para a esposa, como Adonai está para Israel. Assim, a similitude das duplas A-C e B-D confere eloquência à analogia: pastor-Deus e rebanho-Israel, ou esposo-Adonai e esposa-Israel. Esta forma de raciocínio explicita-se na literatura sapiencial, por exemplo, ao mostrar a insensatez da idolatria:

Naturalmente vãos foram todos os homens que ignoraram a Deus e que, partindo dos bens visíveis, não foram capazes de conhecer Aquele que é. Nem, considerando 
as obras, foram capazes de reconhecer o Artífice. Mas foi o fogo, ou o vento, ou o ar sutil, ou a abóbada estrelada, ou a água impetuosa, ou os luzeiros do céu, príncipes do mundo, que eles consideraram como deuses! Se, fascinados por sua beleza, os tomaram por deuses, aprendam quanto Ihes é superior o Senhor dessas coisas, pois foi a própria fonte da beleza que as criou. E se os assombrou sua força e atividade, calculem quanto mais poderoso é Aquele que as formou; pois a grandeza e a beleza das criaturas fazem, por analogia, contemplar o seu Autor. (Sb 13,1-5)

O Novo Testamento desenvolve esta abordagem, não só aplicando os termos comparativos de Pastor e Esposo para Deus - bem como para o Messias Jesus (cf. Lc 15,4-7; Jo 3,29; Jo 10,1-16; Ef 5,25-32) - mas admitindo a analogia como acesso à auto-comunicação divina em sentido universal: a todos os povos, além de Israel, Deus se dá a conhecer por sua ação no mundo, que faz-se objeto do discernimento humano. Ou, como diz o Concílio Vaticano II: "Criando pelo Verbo o universo e conservando-o, Deus proporciona à humanidade, nas coisas criadas, um permanente testemunho de Si” (Dei Verbum 3). Neste sentido, há exemplos neotestamentários: o evangelho de Mateus menciona os "magos [màgoi] que vieram do Oriente" seguindo "a sua estrela [astera]" até "Belém da Judeia" (Mt 2,1-3); João, antes mesmo de atestar a encarnação do Verbo em Jesus, o qualifica como "luz verdadeira [phos alethinon] que ilumina a todo homem [panta ànthropon]" (Jo 1,9); e Paulo admite que os gregos têm acesso à "realidade, poder e divindade" do Criador, que se faz "inteligível através das criaturas" (Rm 1,20). Esses textos são pontuais, mas com valor universal pela inclusão que operam, ao admitir judeus e gregos ao lado de sábios babilônios, persas e árabes (= màgoi) na categoria universal de hermeneutas da Revelação divina (cf. BENOIT, 2013, p. 1705).

A teologia islâmica, por sua vez, segue a mesma linha de raciocínio. A Terra e os montes, a noite e o dia, o firmamento e a luz solar falam da potência divina que os criou: 
Acaso não dispusemos a Terra como um leito; e as montanhas, como estacas de uma tenda? E vos criamos todos em casais. E fizemos do vosso sono um repouso. Criamos a noite como um manto; e o dia, como tempo propício para a vida. E estabelecemos, por cima de vós, os sete firmamentos; e neles pusemos uma luz resplandecente. Enviamos das nuvens a chuva copiosa, para produzir, por meio dela, os cereais, as plantas e frondosos jardins! (Sura 78,1-16)

Aos olhos do Islã, a extensão perceptível do firmamento denota a extensão infinita do poder e onisciência divinos: "Foi Allah quem criou sete firmamentos e outro tanto de terras; e seus desígnios se cumprem, entre eles, para que saibais que Deus é onipotente, Aquele que tudo abrange com sua onisciência" (Sura 65,12). Há, portanto, um conhecimento manifesto, de ordem causal, entre as criaturas e o Criador, que se expressa nos sinais (ayat) visíveis do mundo e pode ser também investigado pela "razão ou intelecto - aql em árabe, da raiz q-l que significa religar ou reter" (ARKOUN, 2007, p. 722). Contudo, o pensamento islâmico não elabora analogias apenas mediante a relação causal entre Criador e criatura, exposta no Alcorão, mas por outras duas vias: a exegese das metáforas ou parábolas, e a investigação dos Nomes divinos presentes no corpus corânico. Vejamos:

a) A via das parábolas - Mais uma vez, o Livro legitima e instiga esta busca teológica, ao dizer: "Temos exposto nesta Récita toda sorte de parábolas [amthal] para os humanos" (Sura 17,89; também nas Suras $18,54 ; 30,58 ; 39,27)$. Em árabe o termo mathal, com seu plural amthal como consta nas Suras, não se restringe a uma estória ou narrativa didática, mas abraça também "o símbolo e todo conjunto de figuras, simples ou complexas" que se apresentam como "comparações cujo significado pode ser explícito ou não” (GRILL, 2007b, p. 633). Deste modo, são do gênero mathal as analogias causais entre Criador e criatura, bem como as lições que Deus proporciona direta ou indiretamente, como: os ventos portadores da chuva (Sura 30,46 ), o pequeno barco que singra as águas imensas (Sura 45,12), o rebanho que provê o leite (Sura 16,66), o traba- 
Iho engenhoso das abelhas (Sura 16,68), a pesca em busca de alimento (Sura 16,14), o contraste entre o calor do deserto e o refrigério do jardim (Sura 2,261-266), a lâmpada de óleo que brilha e afasta a treva (Sura 24,35-36) - esta última, em particular, é uma das parábolas mais comentadas pela teologia e pela mística muçulmana, como veremos a seguir. Cada símbolo ou comparação (mathal) diz algo de Deus: os ventos portadores da chuva mostram Sua misericórdia; o barquinho que volta ao porto com os peixes indica Sua providência; o rebanho que dá o leite e a lã constituem Sua dádiva; a produção do mel nos faz ver Sua ordem e beleza, aos quais as abelhas obedecem; o ardor do deserto adverte sobre o inferno, enquanto o frescor do oásis antecipa o paraíso; enfim, o óleo "que brilha sem ter sido tocado pelo fogo" (Sura 24,35) representa a Luz de Deus, princípio incriado das outras luzes. Como diz o Livro: "a Deus convém a mais bela similitude [mathal]" (Sura 16,60). Daqui nasce a "exegese espiritual" e "escatológica" do Alcorão, como observa Grill (2007b, p. 635), chamada tawil: literalmente "denodar o texto até o fim" ou "levar o texto a seu termo" (GRILL, 2007a, p. 304).

b) A via dos Nomes divinos - O Alcorão diz: "Os mais belos nomes pertencem a Deus: invocai-O" (Sura 7,180); e também: "Quer O invoqueis como Deus [Allah], quer O invoqueis como Clemente [Rahman], sabei que dele são os mais sublimes nomes" (Sura 17,110). De fato, muitas Suras elencam os Nomes divinos, como esta:

Ele é Allah; não há divindade além d'Ele, o Conhecedor do visível e do invisível. Ele é o Clemente [ar-Rahmanu], o Misericordioso [ar-Rahimu]. Ele é Allah; não há divindade além d'Ele: o Soberano [al-Maliku], o Santo [al-Quddusu], a Paz [as-Salamu], o Guardião [al-Mûminu], o Onipotente [al-Muhaîminu], o Fortíssimo [al-Azizu], o Supremo [al-Jabbâru], o Magnífico [al-Mutakabbiru]! Glorificado seja Allah [Deus] acima de tudo o que lhe associam. Ele é Allah, o Criador [al-Khaliku], Aquele que dá origem a todas as coisas [al-Bâriu], Aquele que modela [al-Musawiru]. Seus são os mais belos nomes. $E$ tudo o que existe nos céus e na terra celebra Seu louvor. Ele é o Poderoso [al-Azizu], o Sapientíssimo [al-Hakímu]. (Sura 59,22-24) 
Notemos uma peculiaridade do texto árabe: "os mais belos nomes" (al-asma' al-husna) equivalem aos "mais belos atributos" (ElHAYEK, 1994, p. 329). Então, de que modo nomes e atributos se relacionam? A solução parte de um princípio simples: "podemos conhecer os atributos de Deus através de Seus atos" (SAEED, 2010, p. 121). Ou, como esclarece Ünal (2015, p. 779): "Os atos levam aos nomes; e os nomes levam aos atributos". Este princípio que se opera com três procedimentos complementares entre si, conforme esquema sugerido por Ceylan (1996, p. 86-103)

- $1^{\circ}$ procedimento: conhecer o agir de Deus testemunhado pelo Alcorão; pois seus atos remetem aos atributos, e o conhecimento dos atributos nos autorizam nomear Deus. Assim, reconhecê-Lo pelo ato de criar (bâra, em árabe) nos permitem nomeá-Lo como Criador (al-Bâriu).

- $2^{\circ}$ procedimento: examinar quais Nomes enunciados no Alcorão qualificam a Deus positiva ou negativamente. Assim, invocá-Lo como Sapientíssimo (al-Hakímu) significa, negativamente, que Deus nada ignora ou que n'Ele não existe ignorância.

- $3^{\circ}$ procedimento: estudar os Nomes e as qualidades de Deus, para sistematizar seu conhecimento mediante distinções teológicas, como: quais qualidades referem-se ao agir de Deus (qualidades ativas) e quais referem-se ao ser de Deus (qualidades essenciais); ou ainda quais Nomes $\mathrm{O}$ predicam positivamente $\mathrm{e}$ quais $\mathrm{O}$ predicam negativamente. Deste modo, Clemente qualifica sua essência (al-Rahmanu), enquanto Misericordioso indica seu modo de agir com a humanidade (al-Rahimu); já o nome Luz (Nur) O predica positivamente como "luz dos céus e da terra" (Sura 24,35), e negativamente ao deduzir-se que Deus não seja

3. Sobre os procedimentos e classificações dos Nomes divinos no Islã, cf. CEYLAN, Yasin. Theology and tafsir in the major works of Fakhr al-Din al-Razi. Kuala Lumpur (Malaysia): ISTAC, 1996, p. 86-103. Também: SCATTOLIN, Giuseppe. Dio nell'Islam. In: GAMBA, Alessandro. Cultura, civiltà e teologia nell'lslam. Milano: Marietti, 2003, p. 19-24. 
escuridão, por não submeter-se a nenhuma privação ou carência ontológica.

A investigação dos atributos revelados no Alcorão deu origem à lista dos 99 Nomes divinos a serem rememorados no coração, invocados na adoração e conhecidos pela razão (cf. Sura 7,180). Esta reflexão ocupou a místicos, filósofos e teólogos, como Tabari, Ibn Arabi, Al-Gazali e Al-Razi, resultando numa refinada teologia dos atributos e qualidades de Deus (sifat), classificados de modos diferentes conforme os grandes autores e suas escolas teológicas - um tópico extenso que não cabe em poucas linhas ${ }^{4}$.

Quanto ao nosso tema, importa ressaltar que os grandes comentadores do Alcorão consideram a Luz (Nur) um dos mais belos e sugestivos Nomes divinos, como reza o mesmo Livro no célebre versículo da luz:

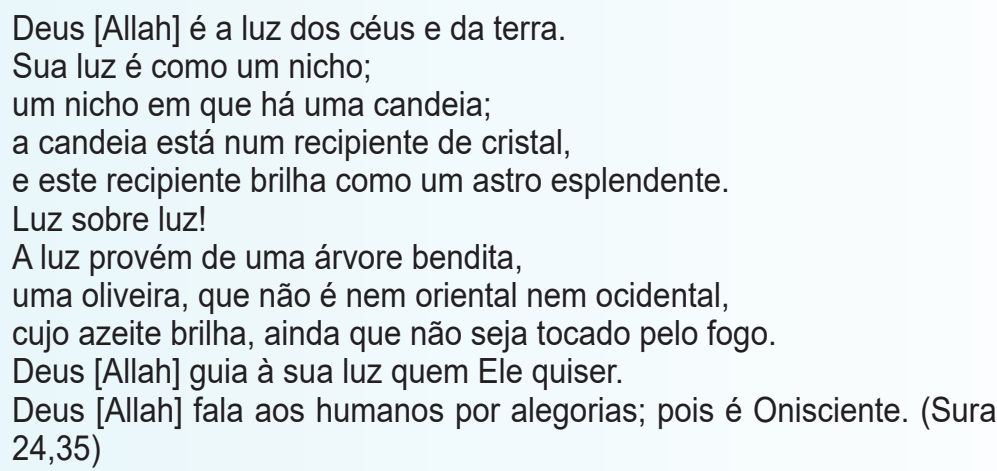

Dizer que "Deus é luz [nur]" e que Ele "fala aos humanos por alegorias [amthal]" é um convite aberto ao estudo de seus atributos, feito com rigor pelos sábios muçulmanos. Para alguns, a luz é metáfora do agir divino: criando o Sol e o dia, Allah se mostra no mundo como origem da luz, ocultando, porém, sua essência absolutamente una e indistinta

4. Para uma introdução à teologia dos Nomes divinos cf. GIMARET, Daniel. Les noms divins en Islam: éxegèse léxicographique et théologique. Paris: Cerf, 1988; também: MANDEL, Gabriel. Os 99 nomes de Deus no Alcorão. Petrópolis: Vozes, 1999. 
(posição chamada mutazilita) $)^{5}$. Para outros, a luz é analogia do ser divino, que Se nomeia como luz incriada e eterna, não percebida fisicamente, mas interiormente, pela fé; de modo que a Luz é uma qualidade inerente à essência de Deus (posição chamada asharita) ${ }^{6}$. Quanto ao versículo da luz (ayat an-nur) da Sura 24,35 transcrito acima, as interpretações sucedem-se ao longo da História. Segundo Tabari (923 d.C.) em seu Comentário ao Alcorão, "a candeia designa o coração do crente iluminado pela fé; o vaso transparente - receptáculo límpido e cristalino - é o peito do fiel: quanto mais transparente for o coração, tanto mais se identificará com a fonte dessa luz" (apud GEOFFROY, 2007, p. 500). O filósofo Ibn Sina (1037 d.C.), por sua vez, entende que "Deus é luz no sentido de causa primeira de todas as coisas; o nicho designa a inteligência; por oliveira compreende-se a reflexão, e por óleo se entende o brilho espontâneo da intuição" (apud GEOFFROY, 2007, p. 500).

Em perspectiva mística destaca-se Al-Gazali (1111 d.C.), com sua teoria dos intelectos ou faculdades da alma exposta na obra Mishkât

5. Posição da escola Mutazila, influente entre os séculos IX e XI, defensora da unidade simples e absoluta de Allah. Os pensadores desta escola não admitem a distinção, em Deus, entre sua essência e seus atributos, ainda que nomeados no Alcorão, pois isso implicaria na multiplicidade da divina natureza. A Mutazila não cancela o papel do intelecto na busca de Deus, mas o restringe rigorosamente em defesa da unicidade absoluta de Allah. Deste modo, os predicados positivos de Deus - sabedoria, eternidade, poder, vida, comunicação etc. - seriam idênticos à Sua essência. Já os predicados circunscritos ao agir de Deus no mundo seriam comparações didáticas para que a humanidade o louve e adore, sem referência ao Ser mesmo de Allah (cf. SAEED, Abdullah. Introdução ao pensamento islâmico. Lisboa: Edições 70, 2006, p. 114-120).

6. Da escola iniciada por Abu Hassan al-Ashari (941 d.C.), donde Asharita, distinta e polemista em relação ao rigorismo mutazilita. Os pensadores asharitas admitem atributos em Deus, enunciados no Alcorão para que o ser humano O conheça, indo dos atos de Deus à contemplação de Sua essência. Os asharitas perscrutam os Nomes divinos enunciados no Alcorão, classificando-os e distinguindo-os da essência divina, como exercício da inteligência crente. Os predicados positivos de Deus - sabedoria, eternidade, poder, vida, comunicação etc. - qualificam o Ser de Deus, como atributos inerentes mas distintos da Sua essência (cf. SAEED, Abdullah. Introdução ao pensamento islâmico. Lisboa: Edições 70, 2010, p. 120-123). 
al-anwâr (= O nicho das luzes $)^{7}$, seu magistral comentário ao versículo da luz. Como sintetiza Gairdner (2003, p. 504), a teoria de Al-Gazali propõe uma ascensão gnosiológica, que vai da apreensão dos primeiros inteligíveis, com conceitos referidos às coisas, até a aquisição dos segundos inteligíveis, com conceitos além das coisas, referidos ao Bem, à Verdade, enfim, a Deus:

Entre as faculdades da alma estão aquelas que a mesma alma possui enquanto necessita desenvolver-se e aperfeiçoar-se, de modo a alcançar o estágio de intelecto em ato [intellectus in actu]. A primeira faculdade é aquela que prepara a alma a receber os inteligíveis: alguns a chamam intelecto material - ou seja, o nicho. Acima desta há uma outra faculdade que a alma possui quando tiver recebido os primeiros inteligíveis, preparando-se então para receber os segundos. Os segundos inteligíveis podem ser adquiridos por reflexão ou por intuição, que é um modo mais firme. A primeira, isto é, a reflexão, é simbolizada pela oliveira; a segunda, que é a intuição, é simbolizada pelo óleo. Em ambos os casos, a alma neste estágio é chamada de intelecto habitual ou intelecto em hábito [intellectus in habitu], sendo como o recipiente de cristal. (GAIRDNER, 2003, p. 504)

A teoria de Al-Gazali admite uma instância mística no conhecimento humano. Como ele mesmo explica, o intelecto acessa a Revelação divina exposta no Alcorão e vislumbra entre o "Rosto de Deus" entre "véus de luz e trevas", numa experiência de "extinção" de si mesmo no mistério, pela graça da união com Allah; união que se dá "além da razão" e favorece um conhecimento que supera a lógica dos filósofos (GHAZALI, 1981 , p. 35, 53, 55, 77). Al-Gazali aproxima-se do Ser divino com um olhar exterior (inteligência da luz revelada, o Alcorão) que conduz ao

7. No presente estudo, usamos principalmente a tradução de Roger Deladrière: GHAZALI. Le tabernacle des lumières (Mishkât al-anwâr). Paris: Seuil, 1981. Os comentários de Gaidner estão em sua tradução e edição da mesma obra, em inglês: AL-GAZALI, Abu Hamid. Mishkat al-anwar [The niche of light]. London: Royal Asiatic Society, 1924, que é citada por Peirone em sua prestigiosa edição italiana do Alcorão: PEIRONE, Federico. II Corano vol. I-II. Milano: Arnoldo Mondadori Editore, 2003 [ristampa dell'edizione di 1984]. Dessas fontes nos vêm as variações na grafia de Al-Gazali ou Ghazali, segundo a transliteração do árabe usada pelos diferentes tradutores e editores. 
olhar interior (inteligência da Luz primeira, Deus), numa escala que vai do visível ao invisível, do dizível ao indizível (cf. GHAZALI, p. 45-46). Assim, ele dispõe os graus de manifestação da luz num movimento ascendente, da luminosidade natural ao atributo divino por Revelação, que está no topo da escala do conhecimento, e conclui:

Quando essas [gradações da luz] mostrarem-se em seus diferentes níveis, então te será claramente manifesto que Deus é a luz suprema e última; e quando Sua profunda natureza te for desvelada, ficará evidente para ti que Ele somente - não havendo nada a Ele associado - é a Luz real e verdadeira. [...] A luz verdadeira é aquela pela qual, à qual e a partir da qual as coisas se revelam, e acima da qual não há luz alguma que seja sua fonte ou à qual ela pudesse recorrer. A luz verdadeira possui esta fonte em si mesma, por si mesma e desde si mesma e não a partir de qualquer outra coisa. Tu sabes, por conseguinte, que tais atributos não pertencem senão à Luz primordial. (GHAZALI, 1981, p. 37 e 55)

Numa outra perspectiva, mais teológica, temos Al-Razi (1209 d.C.) com seu comentário ao Nome divino da Luz (an-Nur). Al-Razi parte da via negativa, demonstrando que a luz natural, enquanto fenômeno finito que pode ser sucedido pela treva, não convém para designar o Ser de Deus:

A luz [nur] é o Nome que convém àquela qualidade cujo contrário é a Obscuridade (zhalam). Ora, é certamente impossível que Allah - glória a Ele - seja qualificado deste modo, por várias razões: Uma primeira razão: Esta qualidade (kayfiyya) termina por desaparecer, ao contrário daquela do Verídico Deus. Uma segunda razão: Os corpos enquanto tais são indiferenciados em relação à Luz; mas são diferenciados em relação à luminosidade (diya) e à obscuridade (zhulma). A luminosidade é, pois, um modo inerente ao corpo, que dela necessita [para mostrar-se], ao contrário do Ser Necessário [que existe e manifesta-se por Si mesmo]. Uma terceira razão: A luz se opõe à obscuridade. Ora, o Verídico Deus é por demais majestoso para ter algo que Lhe seja contrário ou Lhe seja aparentado. (AR-RAZI, 2009, p. 589) ${ }^{8}$

8. As variações de grafia de Al-Razi e Ar-Razi dependem da transliteração usada pelos tradutores e editores, pois o artigo definido $A l$ que antecede o nome é pronunciado, em árabe, como Ar por assimilação da consoante-forte $R$ em Razi. 
Deste modo, preserva-se Allah em sua majestade e inefabilidade. Mais adiante, considerando as afirmações da Sura 24,35 (Deus é luz... Luz sobre luz), Al-Razi aproxima-se da via positiva e explica em que sentido pode-se nomear a Deus como Luz:

A luz aparente é aquela que manifesta toda coisa oculta. Ora, esta ocultação [khafa] não é senão pura privação ou potencialidade ['adam], enquanto que a manifestação [zhuhur] é existência [whujud]. O Verídico Allah é o existente [mawjud] não passível de privação; além disso, a privação, por modificar-se, não é mais caracterizada como simples obscuridade ou treva. Já o Verídico - glória a Ele - é Aquele por quem toda coisa, exceto Ele mesmo, adquire a existência. Ele é a Luz de toda obscuridade e a manifestação de tudo quanto se ocultava. De modo que Allah é a Luz incondicionada [nur mutlaq]. Mais que isto! Ele é Luz das luzes ou, como se lê, Luz sobre luz [nur al-anwar]. (AR-RAZI, 2009, p. 590)

O raciocínio de Al-Razi está posto entre duas margens: de um lado, a afirmação da absoluta alteridade de Deus, irredutível e incomparável às coisas criadas; de outro lado, o sentido análogo dos atributos divinos nomeados no Alcorão, como Luz, numa hermenêutica autorizada pelo Livro sagrado. Em suma, Deus não pode ser identificado com o Sol nem outra forma de luz; mas pode ser nomeado como "Luz dos céus e da terra" (Sura 24,35) enquanto Criador do Sol e da Lua, donde provêm a luz diurna e noturna, sendo também Criador da oliveira, donde provém o óleo das lâmpadas. Deste modo, Al-Razi desenvolve um raciocínio dialético que admite a cognoscibilidade de Deus por Revelação, respeitando simultaneamente a natureza humana (intérprete da Revelação) e a natureza divina (não só objeto, mas autora da Revelação); estas duas naturezas se comunicam, mas permanecem assimétricas por sua diferença ontológica.

A menção corânica à "árvore bendita" - isto é, "a oliveira" [az-zeytuna] cujo óleo "brilha sem ser tocado pelo fogo" (Sura 24,35) também recebeu interpretação variada. Suhrawardi (1191 d.C.) vê aqui a representação "de Deus como um clarão primordial, energia da qual 
procede a manifestação de todo o universo" (GEOFFROY, 2007, p. 500). Al-Gazali, de seu lado, opina que "a frase cujo azeite brilha, ainda que não seja tocado pelo fogo é aplicável à alma nobre possuidora de santidade" (GAIRDNER, 2003, p. 504). "De fato - pondera Al-Gazali (1981, p. 81 ) - há santos cuja luz brilha quase por si mesma, a tal ponto que eles quase poderiam dispensar a assistência dos profetas".

\section{Entre o oculto e o manifesto}

Na literatura religiosa cristã e muçulmana, a luz se inscreve como termo análogo com função representativa, mas nunca como termo unívoco ou equívoco; pois as narrativas mantêm, simultaneamente, uma aproximação e uma distância - por vezes uma tensão - entre o Deus absconditus (a Quem não se vê) e o Deus revelatus (cuja Face irradia forte clarão). De um lado, os textos admoestam: "Não poderás ver a minha face [diz o Senhor]; porque o homem não pode ver-Me e continuar vivendo" (Êx 33,10); e também "Tal é Allah, vosso Senhor: os olhares não podem percebê-lo" (Sura 6,102.103). Mas, por outro lado, os textos também dizem: "Adonai [IHWH] falava com Moisés face a face, como um homem fala com seu amigo" (Êx 33,11); e no Alcorão: "O coração do mensageiro [Muhammad] não mentiu acerca do que viu" (Sura 53,11). Ver e não ver a Face divina se encontram, também, neste hadith reportado por Al-Gazali (1981, p. 35-36): “Allah se esconde por trás de setenta véus de luz e de trevas; se Ele os removesse, a glória fulgurante de Sua face consumiria qualquer um que fosse atingido por Seu olhar".

A tensão muitas vezes paradoxal entre $o$ velado e o manifesto remete ao caráter dadivoso da Revelação divina, sempre graça e nunca

9. Al-Gazali fala dos místicos (= santos) e da revelação profética contida no Alcorão (= profetas); admite a luz interior dos santos, nos quais já fulgura a Luz primordial que é Allah; mas não descarta a luz revelada do Livro, considerado Palavra divina. Notemos que Al-Gazali usa duas vezes "quase" na sua ponderação, sugerindo uma distinção fenomênica entre experiência mística e revelação profética, mas preservando a verdade das Escrituras. Pois crê que, vindas da mesma Luz primordial, tanto a experiência mística quanto a revelação corânica corroboram a mesma verdade sobre Deus. 
simples resultado de deduções lógicas. Neste sentido, a luz que irradia-se da face de Deus por sobre nossas faces, afastando a treva e o erro, é uma analogia da Revelação usada em Êxodo 34 e reinterpretada pelo apóstolo Paulo. O Livro do Êxodo diz:

Quando Moisés desceu da montanha do Sinai, trazendo nas mãos as duas tábuas do Testemunho, sim, quando desceu da montanha, não sabia que a pele de seu rosto resplandecia porque havia falado com Ele. Olhando Aarão e todos os israelitas para Moisés, eis que a pele de seu rosto resplandecia; e tiveram medo de aproximar-se dele. Moisés, porém, os chamou; Aarão e os chefes da comunidade foram até ele; e Moisés Ihes falou. Depois aproximaram-se todos os israelitas, e ordenou-lhes tudo o que Adonai [IHWH] havia dito sobre a montanha do Sinai. Quando Moisés terminou de lhes falar, colocou um véu sobre a face. Quando Moisés entrava diante de Adonai [IHWH] para falar-Lhe, retirava o véu, até o momento de sair. Ao sair, dizia aos israelitas o que lhe havia sido ordenado, e os israelitas viam resplandecer o rosto de Moisés. Depois Moisés colocava o véu sobre a face, até que entrasse para falar com Ele. (Êx 34,29-35)

No Novo Testamento, Paulo retoma esta passagem e a aplica à Revelação de Jesus Cristo nas linhas de 2Cor 3,12 até 4,6. Pouco antes, na Carta aos Romanos, o apóstolos observara que o conhecimento de Deus pode dar-se pelo intelecto, uma vez que "Sua realidade invisível - como Seu poder e divindade - tenha-se tornado inteligível, desde a criação do mundo, através das criaturas" (Rm 1,20). Contudo, o mesmo apóstolo adverte que "o nosso conhecimento é limitado" (1Cor 13,9) e fala da Revelação em termos relacionais, como um encontro com Deus de natureza histórico-escatológica: "Agora vemos em espelho e de maneira confusa; mas, depois, veremos face a face" (1Cor 13,12). Para o apóstolo, dispor-se a este encontro face a face é condição para que Deus Se desvele, e desvele a nós próprios diante d'Ele; para fazer "cair o véu" que nos cobre "a face" e "o coração" (2Cor 3,15-17). Esta Revelação mediante o encontro humano-divino confere um conhecimento novo a respeito de Deus, que é o conhecimento de sua Palavra Viva, o 
Messias Jesus, capaz de transformar a quem recebe sua luz: "Todos nós que, com a face descoberta, contemplamos como num espelho a glória do Senhor [dòxa Kyriou], somos transfiguramos nesta mesma imagem, cada vez mais resplandecente" (2Cor 3,18$)$. A esta Revelação, dádiva e encontro com Deus no seu Verbo encarnado, Paulo denomina "luz do Evangelho" (2Cor 4,4). Por fim arremata: "Porquanto Deus - que disse: Do meio das trevas brilhe a luz! [Gn 1,3] - foi Ele mesmo quem reluziu em nossos corações, para fazer brilhar o conhecimento da glória de Deus, que resplandece na face de Cristo" (2Cor 4,6). Mais uma vez, vale notar, não se trata de desprezar o intelecto humano, mas de preservar a Deus como o autor inefável da Palavra (dabar para os judeus; logos para os cristão; kalima para os muçulmanos). Palavra revelada, comunicada como mensagem que se ouve e luz que se contempla.

Na tradição cristã, o Pseudo-Dionísio em sua obra Os nomes divinos IV,7 (2004, p. 45) diz que Deus "é celebrado como o Bem", a quem "os teólogos chamam de Belo, Beleza, Amor, Amável, e de todos os outros nomes divinos adequados". Diz ainda que, em relação ao intelecto humano, pode-se atribuir a Deus luz e treva simultaneamente: a luz nomeia Deus de modo positivo, por tudo o que dele inteligimos; mas a treva também $O$ pode nomear, negativamente, por tudo o que dele não somos capazes de conceber. Em sua Teologia mística I,1 o mesmo autor admite: sendo Deus "Aquele que é além de toda essência e de todo saber", deverá ser nomeado "Treva" e "Silêncio" (PSEUDO-DIONÍSIO, 2004, p. 129-130). Donde seu ensino místico-teológico proposto na obra Os nomes divinos IV,5: por um lado, "cabe-nos celebrar o Bem sob o título de Luz inteligível e dizer que o Bem é chamado Luz inteligível porque ele cumula todas as inteligências supracelestes com luz inteligível, porque ele dissipa toda ignorância e todo erro de todas as almas onde penetra e a todas concede o dom de sua santa luz" (PSEUDO-DIONÍSIO, 2004, p. 44). Mas, por outro lado, também "chamamos a Luz inacessível de Treva incompreensível e invisível, porque ela transcende a luz que se vê" (Os nomes divinos VII,2: PSEUDO-DIONÍSIO, 2004, p. 92). Esta dialética 
entre saber e não-saber, que inquieta a inteligência crente, se resolve com a mesma luz que o Bem concede ao revelar-Se:

Chama-se, portanto, Luz inteligível este Bem [divino] que está além de toda luz, porque ele é fonte de toda iluminação e difunde o mais pleno de sua luz sobre toda inteligência; quer se trate daquelas que ultrapassam este mundo [sensível], daquelas que o envolvem ou daquelas que aí permanecem, é Ele que as ilumina com toda sua plenitude, que renova suas capacidades de intelecção, que as contém todas por sua extensão, e as supera, por sua transcendência. (Os nomes divinos IV,6: PSEUDO-DIONÍSIO, 2004, p. 45).

De modo semelhante, entre os autores muçulmanos, Abu Hassan Al-Ashari (874-936 d.C.) admite que as qualidades de Deus sejam conhecidas a partir do Alcorão, respeitando-se sempre a extensão de suas afirmações textuais. Pois especular em terrenos aos quais o Alcorão não adentra seria um alto risco, segundo Al-Ashari. Uma vez que "Deus é distinto de qualquer outra coisa além d'Ele mesmo, seria falta de reverência propor analogias, comparações ou semelhanças que se vinculem à Sua excelsa natureza. [...] Deste modo, Al-Ashari confirma os atributos de Deus, mas rejeita que Lhe seja atribuída qualquer qualidade que $O$ associe aos seres criados" (EL-BIZRI, 2008, p. 130)10. Neste caso, associar criaturas ao Criador significa atribuir-Ihes qualidades exclusivas de Deus, ou atribuir a Deus as propriedades da criatura - como composição ou geração - em prejuízo da absoluta unicidade de Allah. De fato, a unicidade divina é a norma mais rigorosa para a aplicação de analogias e alusões ao Deus Revelado:

El gran teólogo Al-Ashari ha desarrollado un punto de vista más sutil, tendente a un arreglo que permita conciliar la transcendencia de Dios con el carácter inteligible y directo y con la importancia real de la revelación manifestada en un leguaje humano. El lenguaje de la revelación es el fundamento y la norma del lenguaje teológico

10. Aqui, El-Bizri (2008, p. 130) remete a Al-Ashari: Kitab al-luma [The luminous book]. Cairo: Ed. Hammuda Ghuraba, 1955, p. 20-26; a frase de Al-Ashari está em itálico: Deus é distinto de qualquer outra coisa além d'Ele mesmo. 
acerca de Dios - subraya Al-Ashari. Además, el lenguaje humano de la revelación se refiere a la realidad de Dios y la expresa, y desde luego en unas afirmaciones inteligibles, puesto que entre Dios y el mundo existe una analogía. [...] Y es que lo más importante en todo este asunto no es el lenguaje humano, en el que se expresan las propiedades divinas, sino justamente la realidad divina, que ha de expresarse en forma de alusiones. De este modo, el hablar de Dios es un lenguaje que está referido a la realidad y que descubre y manifiesta unas propiedades reales de Dios, aun cuando después resulten difíciles de definir. (KHOURY, 2000, p. 168-169)

Pseudo-Dionísio e Al-Ashari propõem uma lição teológica fundamental: ainda que Deus seja-nos inteligível e concebível, professado com categorias ontológicas e hermenêuticas, nunca será redutível ao que d'Ele podemos inteligir e conceber. Donde os apelativos de Luz e Treva que a inteligência humana Lhe pode atribuir. Notemos, porém, que este posicionamento não é arbitrário, da parte desses autores, mas decorre do exame de sua respectiva literatura sagrada - a Bíblia e o Alcorão.

Na Bíblia, o Salmista diz que Deus "fez das trevas seu véu; e sua tenda, de águas escuras e nuvens espessas" (SI 18,12); diz ainda que reconhece a luz no mundo criado, em virtude da Luz divina: "Com tua luz, nós vemos a luz" (SI 36,10). No Novo Testamento, Paulo recorda a Timóteo que Deus "habita uma luz inacessível, que nenhum homem viu, nem pode ver" $(1 \mathrm{Tm} 6,16)$. Ao revelar-se, porém, na Face de Cristo, se manifesta como "Luz verdadeira que ilumina todo homem" (Jo 1,9).

Da parte muçulmana, o Alcorão adverte que a Revelação é graça, pela qual Deus concede à humanidade participar do incognoscível, do inefável que escapa à visão habitual: "Ele possui as chaves do invisível, que somente Ele conhece" (Sura 6, 59); "Esses são relatos do incognoscível, que agora te revelamos" (Sura 3,44). Neste sentido, o Islã nomeia a récita ou proclamação da Palavra de Deus aos povos da Aliança como luz (nur) e claridade (diyá); não somente o Alcorão - que é a Récita (al-Quran) por excelência - mas também a Torah de Moisés e o Evangelho 
de Jesus: "Revelamos a Torah, que encerra orientação e luz, com a qual os profetas, submissos a Deus, julgam os judeus [...]" (Sura 5,44$)$. "E depois deles [dos profetas] enviamos Jesus, filho de Maria, corroborando a Torah que o precedeu; e Ihe concedemos o Evangelho, que encerra orientação e luz: uma confirmação do que foi relevado na Torah e uma exortação para os tementes" (Sura 5,46).

\section{Considerações finais}

A literatura bíblica e corânica examinadas aqui, com o suporte de autores clássicos do Cristianismo e do Islã, nos permitem três observações finais a respeito de Deus como Luz (ademais do conteúdo material já exposto). Em primeiro lugar, constatamos que à solarização das divindades mesopotâmicas, médio-orientais e egípcias, corresponde a de-solarização radical do Deus Único semita, nos mesmos cenários geoculturais. Bíblia e Alcorão, nas muitas passagens examinadas, demonstram o insistente processo de afirmação do monoteísmo de raiz abraâmica na literatura e na teologia dos respectivos credos. Processo de duplo efeito: à medida que se argumenta a unicidade do Deus Criador, argumenta-se também sobre as criaturas a Ele referidas. Desenvolvem-se, simultaneamente, uma teologia da Revelação e uma teologia da Criação. Essas não se justapõem, nem se contrapõem, mas têm no ser humano seu ponto de tensão por sua condição de intérprete da Palavra divina no mundo. Tensão que se evidencia na dialética entre o oculto e o manifesto, o inefável e o inteligível, com seus reflexos no plano da linguagem religiosa, ora tendendo à mística (como Pseudo-Dionísio e Al-Gazali), ora tendendo à lógica (como a literatura bíblica sapiencial e Al-Ashari). Dizemos aqui "tendendo a" porque se trata de um argumento pendular, não simplista nem disjuntivo, seja na literatura sacra, seja nos comentadores citados. Assim o demonstra a literatura neotestamentária, que ora expõe, ora oculta o Mistério divino, bem como o Pseudo-Dionísio para quem Deus pode ser nomeado coerentemente Luz ou Treva. Também o demonstram as Suras corânicas, que afirmam a cognoscibilidade de 
Allah enquanto Luz, cuidando, porém, em distingui-Lo de qualquer criatura e fenômeno natural. As mesmas Suras deram origem a uma intrincada hermenêutica, desde a interpretação filosófica de Al-Ashari (vizinha da lógica aristotélica) àquela mística de Al-Gazali (próxima à elevação platônica).

Isto nos leva à segunda observação: mística e dialética tratam de Deus como Luz, cada qual em seu método, com elementos de convergência e de divergência. Mística e dialética divergem quanto à analogia da luz aplicada ao Ser divino: para os autores bíblicos proféticos, sapienciais e em parte Paulo, a luz é prioritariamente um fenômeno sensível, aplicável a Deus por analogia ou metáfora, como recurso de linguagem no processo de receber e transmitir a Revelação. Nega-se a divindade do Sol e dos luminares em geral, enquanto esses emprestam sua luminosidade para que se reconheça a Deus, chamado Luz, embora tal nome não defina sua ontologia. Enquanto a luz natural é finita, podendo ser sucedida pela escuridão, atribui-se à luz de Deus as qualidades próprias da divindade: "eterna" (Sb 7,26), "verdadeira" (Jo 1,9), "esplendente" (2Cor 4,4), "inacessível" (1Tm 6,16) e "admirável” (1Pd 2,9). Da parte muçulmana, a divergência entre mística e dialética mostra-se na distinção de Al-Gazali com os demais comentadores do Alcorão. Para Al-Razi e Al-Ashari, a luz é antes de tudo uma realidade aparente, própria do Sol, da Lua, das estrelas e do fogo; sendo atribuível a Deus por analogia, de modo que as divinas qualidades se façam inteligíveis ao ser humano. Para Al-Gazali dá-se o inverso: "somente Deus é Luz em sentido próprio", aplicando-se "às demais criaturas apenas em sentido metafórico" - como ele diz, mais de uma vez, na obra Mishkât al-Anwâr (1981, p. 28, 50 e 56). Se aqui temos a divergência, em que ponto mística e dialética convergem ao tratar de Deus como luz? Basicamente, no campo da ontologia divina: as duas respostas admitem a Deus como Ser ontologicamente distinto, único em sua essência. Expliquemos: a concepção de Divindade auto-subsistente, eterna e transcendente, Causa de todas as demais criaturas - como dito nos respectivos Livros sagrados - não é 
tematizada igualmente pelo dialético e pelo místico, mas os leva a concordar que Deus, por ser divino, é Ser de modo próprio - distinto do modo de ser dos demais seres não-divinos. Portanto, quanto à divindade, temos aqui um consenso simples e fundamental, como disse Tomás de Aquino na Quaestio XIII, Art. 1 da $1^{\text {a }}$ Parte da Summa em resposta ao Pseudo-Dionísio: "Dizemos que Deus não tem nome ou está acima de qualquer denominação, porque a sua essência sobrepuja o que dele inteligimos e exprimimos pela palavra" (2004, p. 211). Notemos que se trata de consenso quanto à divindade. Não de consenso geral, quanto à intelecção dos modos de comunicação de Deus à humanidade, especificamente no Cristianismo e no Islã. Nisto há diversidade e alguma divergência, como exposto nas páginas do presente estudo. Pois o Ser de Deus é comunicável - como dito na Bíblia e no Alcorão - ainda que sua essência não se esgote nos Nomes divinos ali comunicados. Alguns classificam os Nomes de Deus em atributos de essência e atributos de ação, identificando os primeiros com a essência mesma de Deus (escola Mutazilita); outros classificam os atributos nas categorias de positivos, negativos e relativos, sempre distintos da essência divina, advertindo que as qualidades positivas de Deus dispostas no Alcorão não exaurem nosso conhecimento do Ser de Deus (escola Asharita).

A terceira observação é a vigência da luz na linguagem e na hermenêutica referidas a Deus, no Cristianismo e no Islã, a despeito de quanto as divergências a poderiam desgastar. Nenhuma literatura a cancela; nenhum autor a despreza. Antes, a luz permanece adequada para falarmos de Deus, conforme estabelecido nos Livros sagrados e tematizado nos comentadores, sejam cristãos, sejam muçulmanos. Há nela um intrínseco valor poético, antes que teológico; e um valor estético, antes que literário, no sentido antropológico de aesthesis: vivência de inserção no tempo e no espaço, na intersecção do sentidos e da memória, forjadora de símbolos e doadora de sentido, pré-lógica em sua manifestação, inteligível em sua assimilação. Toda linguagem e toda escrita da luz que possamos atribuir a Deus, nasce da experiência originária de 
viver e sobreviver sob o Sol, com claridade e calor, atravessando dias de verão e noites de primavera, reunindo-nos abaixo das estrelas e ao redor do fogo. As criaturas acendem a fogueira, que logo se apaga; o Criador acende os luminares cósmicos, que permanecem dia e noite. Aqui está a raiz recôndita da estética e da teologia da luz, aproximando o Transcendente do imanente, o Eterno do finito, o Imenso do pequeno, o Divino do humano. Por via dialética ou por via mística, a humanidade tem encontrado a Deus neste percurso de luz e treva: "Os céus narram a glória de Deus; e o firmamento proclama a obra de suas mãos. O dia entrega a mensagem ao outro dia; a noite a faz conhecer à outra noite" (SI 19,2-3); "De Allah são os louvores nos céus e na terra! E entre seus sinais está o vosso dormir durante a noite e, durante o dia, a vossa busca por Sua dádiva. Certamente, nisto há sinais para os que escutam" (Sura $30,18.23)$. Desta sorte, sejam místicos ou dialéticos, cristãos ou muçulmanos, todos podem aclamar: "Deus é luz" (1Jo 1,5; Sura 24,35).

\section{Referências}

AL-GAZALI, Abu Hamid. Mishkat al-anwar [The niche of light]. Tradução de William H. Temple Gairdner London: Royal Asiatic Society, 1924.

AL-TABARI, Abu Jafar. Jami' al-bayan 'na-tawtl ay al-Quran [Commentary on the Quran]. Oxford: Oxford University Press, 1989.

AL-ASHARI, Abu Hassan. Kitab al-luma [The luminous book]. Cairo: Ed. Hammuda Ghuraba, 1955.

ARKOUN, Mohammed. Raison. In: AMIR-MOEZZI, Mohammad Ali (dir.). Dictionnaire du Coran. Paris: Robert Laffont, 2007, p. 721-728.

AR-RAZI, Fakhr ad-Din. Traité sur les noms divins. Introduction, traduction et annotations par Maurice Gloton. Paris: Albouraq, 2009.

BÍBLIA de Jerusalém. Nova edição revista e ampliada. São Paulo: Paulus, 2002.

CONCÍLIO VATICANO II. Constituição dogmática Dei Verbum sobre a divina Revelação. In: Compêndio do Vaticano II. 22a ed. Petrópolis: Vozes, 1991, p. 119-139 [números marginais 161-199].

EL-BIZRI, Nader. God: essence and attributes. In: WINTER, Tim (ed.). Classical Islamic Theology. Cambridge (UK): Cambridge University Press, 2008, p. 121-140. 
ELIADE, Mircea. História das crenças e das ideias religiosas vol. 1. Rio de Janeiro: Zahar, 2010.

BENOIT, Pierre. Tradução e notas ao Evangelho de Mateus. In: Bíblia de Jerusalém. 9ạ reimpressão. São Paulo: Paulinas, 2013, p. 1705.

BOYER, Régis. La experiencia de lo Sagrado. In: RIES, Julien (coord.). Tratado de antropología de lo Sagrado vol. 1. Madrid: Trotta, 1995, p. 55-74.

CARREIRA, Paulo. Textos da religião de Aton. In: Revista Lusófona de Ciência das Religiões. Lisboa, ano III, 2004, n. 5-6, p. 231-262.

CEYLAN, Yasin. Theology and tafsir in the major works of Fakhr al-Din al-Razi. Kuala Lumpur (Malaysia): ISTAC, 1996.

DODD, Charles Harold. A interpretação do quarto Evangelho. São Paulo: Paulinas, 1977.

DUCHESNE-GUILLEMIN, Jacques. Mazdéisme. In: POUPARD, Paul (dir.). Dictionnaire des religions vol 2. 3a éd. Paris: PUF, 1984, p. 1273-1279.

EL-HAYEK, Samir. O significado dos versículos do Alcorão Sagrado. São Paulo: MARSAM, 1994.

GAIRDNER, William H. T. Mystic interpretation of the Verse of Light. In: PEIRONE, Federico. II Corano vol. I. Milano: Mondadori, 2003 [ristampa dell'edizione di 1984], p. 503-504.

GEOFFROY, Éric. Lumière et ténèbres. In: AMIR-MOEZZI, Mohammad Ali (dir.). Dictionnaire du Coran. Paris: Robert Laffont, 2007, p. 498-500.

GHAZALI. Le tabernacle des lumières (Mishkât al-anwâr). Traduction et commentaire par Roger Deladrière. Paris: Seuil, 1981. Disponível em: <https://pt.scribd.com/doc/247131042/Ghazali-Le-Tabernacle-desLumieres-pdf>. Acessado em 16-06-2018.

GIMARET, Daniel. Les noms divins en Islam: éxegèse léxicographique et théologique. Paris: Cerf, 1988.

GRILL, Denis. Exégèse mystique. In: AMIR-MOEZZI, Mohammad Ali (dir.). Dictionnaire du Coran. Paris: Robert Laffont, 2007a, p. 300-312.

GRILL, Denis. Paraboles et symboles. In: AMIR-MOEZZI, Mohammad Ali (dir.). Dictionnaire du Coran. Paris: Robert Laffont, 2007b, p. 633-638.

IQBAL, Muzaffar. O Islã tradicional e a ciência moderna. In: PETERS, T.; BENNETT, G. (orgs.). Construindo pontes entre a ciência e a religião. São Paulo: Loyola, 2009, p. 185-196.

KHOURY, Adel. Los fundamentos del Islam. 2a ed. Barcelona: Herder, 2000.

MANDEL, Gabriel (trad.). Il Corano: testo arabo con la versione letterale integrale. Milano: UTET, 2004. 
MANDEL, Gabriel. Os 99 nomes de Deus no Alcorão. Petrópolis: Vozes, 1999.

NOJA, Sergio. L'implorare la pioggia. L'eclissi. In: VACCA, Virginia; NOJA, Sergio; VALLARO, Michele (a cura di). Detti e fatti del profeta dell'Islam. Torino: UTET, 2009, p. 175-182.

PEIRONE, Federico. II Corano vol. I-II. Milano: Mondadori, 2003 [ristampa deIl'edizione di 1984].

PSEUDO-DIONÍSIO AREOPAGITA. Obra completa. São Paulo: Paulus, 2004.

SAEED, Abdullah. Introdução ao pensamento islâmico. Lisboa: Edições 70, 2006.

SCHÖKEL, Alonso (trad.). Bíblia do peregrino. São Paulo: Paulus, 2002.

SCHÖKEL, Alonso; CARNITI, Cecilia. Salmos II: tradução, introdução e comentários. São Paulo: Paulus, 1998

SCATTOLIN, Giuseppe. Dio nell'Islam. In: GAMBA, Alessandro (a cura). Cultura, civiltà e teologia nell'Islam. Torino: Marietti, 2003, p. 9-32.

TOMÁS DE AQUINO. Questão XIII - Dos nomes divinos. In: Seleção de textos. São Paulo: Nova Cultural, 2004, p. 209-244.

ÜNAL, Ali. O Alcorão: Com interpretação anotada. New Jersey: Tughra Books, 2915. 